DOI: $10.19195 / 0137-1134.114 .16$

\author{
ELŻBIETA URA
}

Uniwersytet Rzeszowski

eura@univ.rzeszow.pl

\title{
„UCYWILNIANIE” DOTYCHCZASOWYCH STOSUNKÓW SŁUŻBOWYCH FUNKCJONARIUSZY CELNYCH W ZWIĄZKU Z REFORMĄ ADMINISTRACJI CELNO-SKARBOWEJ - W KONTEKŚCIE ZASADY PRAWORZĄDNOŚCI
}

\begin{abstract}
Abstrakt: Z dniem 1 marca 2017 roku weszły w życie ustawy reformujące system administracji celno-skarbowej. Wprowadziły one nie tylko zmiany w systemie organów i struktury organizacyjnej tej administracji, lecz także istotnie wpłynęły na status prawny funkcjonariuszy istniejącej do tego czasu Służby Celnej. Nie wszystkim funkcjonariuszom zaproponowano dalsze pełnienie służby w nowo utworzonej strukturze administracji celno-skarbowej. Część z nich otrzymała propozycje zatrudnienia na stanowiskach cywilnych, części w ogóle nie zatrudniono. W obu przypadkach nastąpiło wygaśnięcie stosunku służbowego, co w świetle przyjętych rozwiązań ustawowych traktowane jest jak zwolnienie ze służby. Bardzo duża grupa funkcjonariuszy złożyła odwołania do sądów administracyjnych, część z nich — również do sądów powszechnych. Na tle tak sformułowanych przepisów powstaje przede wszystkim pytanie: czy „ucywilnienie” funkcjonariusza Służby Celnej i zmiana jego statusu prawnego wynikająca ze zmiany administracyjnoprawnego stosunku służbowego na stosunek pracy, dokonana przez dyrektora izby administracji skarbowej w ramach powierzonych mu dyskrecjonalnych uprawnień, jest zgodna z zasadą praworządności. Odpowiedź na to pytanie ostatecznie zostanie udzielona przez sądy. W opracowaniu natomiast zostaną przedstawione ogólne spostrzeżenia odnoszące się do istniejącej sytuacji.
\end{abstract}

Słowa kluczowe: reforma administracji celno-skarbowej, funkcjonariusz Służby Celnej, prawo do sądu, zwolnienie ze służby

\section{WSTĘP}

Z dniem 1 marca 2017 roku weszły w życie ustawy reformujące system administracji celno-skarbowej. Ukazanie zarysu wprowadzonych zmian i telegraficzny skrót stanu prawnego istniejącego do tego czasu jest konieczne do rozwinięcia zasadniczego wątku rozważań. Wątkiem tym jest przedstawienie sytuacji prawnej byłych funkcjonariuszy Służby Celnej, którym dyrektor izby administracji skar- 
bowej przedstawił propozycję dalszego zatrudnienia w jednostkach KAS, ale nie w ramach stosunku służbowego, lecz stosunku pracy, w wyniku czego dochodzi do „ucywilnienia” dotychczasowych stosunków służbowych. Takie działania zostały uznane przez byłych funkcjonariuszy za naruszające podstawowe zasady Konstytucji RP i zaskarżone do sądów administracyjnych. W publikacji przedstawione zostaną podnoszone w treści odwołań zarzuty i wskazane wątpliwości sądów orzekających co do przyjętych rozwiązań z punktu widzenia zasady praworządności, zasady równości, praw nabytych i prawa do sądu.

\section{STRUKTURA ORGANIZACYJNA I SYSTEM ORGANÓW ADMINISTRACJI CELNO-SKARBOWEJ}

W stanie prawnym obowiązującym do dnia wprowadzenia reformy ${ }^{1}$ administracja celno-skarbowa funkcjonowała w strukturze terenowej zdekoncentrowanej jako administracja niezespolona, skupiona w trzech niezależnie funkcjonujących pionach:

— administracja podatkowa (16 izb skarbowych oraz 400 urzędów skarbowych),

— Służba Celna (16 izb celnych, 45 urzędów celnych wraz z 141 oddziałami celnymi),

— kontrola skarbowa (16 urzędów kontroli skarbowej).

Organami tej administracji byli odpowiednio: dyrektorzy izb skarbowych, dyrektorzy izb celnych, dyrektorzy urzędów kontroli skarbowej oraz naczelnicy urzędów skarbowych i naczelnicy urzędów celnych. Ich aparatem pomocniczym były izby i urzędy. Aparat celno-skarbowy (przy przyjęciu obecnej nazwy) zatrudniał ponad 65 tys. pracowników i funkcjonariuszy (tylko w izbach celnych zatrudnionych było ponad 15 tys. pracowników i funkcjonariuszy) ${ }^{2}$.

Reforma tego sektora administracji rządowej wprowadzona została ustawą z 16 listopada 2016 roku o Krajowej Administracji Skarbowej (dalej: ustawa o KAS) $)^{3}$ i ustawą z tego samego dnia - Przepisy wprowadzające ustawę o Krajowej Administracji Skarbowej (dalej: ustawa wprowadzająca) ${ }^{4}$. Motywem tej re-

1 Należy tu rozumieć ustawy z dnia: 28 września 1991 r. o kontroli skarbowej (tekst jedn. Dz.U. z 2016 r. poz. 720); 21 czerwca 1996 r. o urzędach i izbach skarbowych (tekst jedn. Dz.U. z 2015 r. poz. 578 ze zm.); 27 sierpnia 2009 r. o Służbie Celnej (tekst jedn. Dz.U. z 2016 r. poz. 1799); 10 lipca 2015 r. o administracji podatkowej (Dz.U. z 2015 r. poz. 1269 ze zm.).

2 E. Ura, S. Pieprzny, Reforma administracji celno-skarbowej przyczyna wygaśnięcia stosunków zatrudnienia z mocy prawa pracowników i funkcjonariuszy tej administracji, [w:] Przemiany cywilizacyjne a funkcjonowanie administracji publicznej. Księga jubileuszowa dedykowana Profesorowi Bronisławowi Jastrzębskiemu w dziewięćdziesiąta rocznicę urodzin, red. J. Strzelecki, M. Giżyńska, Płock 2017, s. 181.

3 Tekst jedn. Dz.U. z 2018 r. poz. 508 ze zm.

4 Dz.U. z 2016 r. poz. 1948 ze zm. 
formy była, zdaniem jej twórców, zbyt duża dekoncentracja rzeczowa i terenowa administracji podatkowej, celnej i kontroli skarbowej oraz związana z tym jej niewydolność 5 .

Głównymi celami reformy, zgodnie z uzasadnieniem do projektu ustawy, było między innymi ograniczenie skali oszustw podatkowych; zwiększenie skuteczności poboru należności podatkowych i celnych; obniżenie kosztów funkcjonowania administracji skarbowej w relacji do poziomu uzyskiwanych dochodów budżetowych i rozwój profesjonalnej kadry.

Na mocy nowych ustaw powołano Krajową Administrację Skarbową (KAS), podporządkowaną ministrowi właściwemu do spraw finansów publicznych w miejsce dotychczas funkcjonujących: administracji podatkowej, kontroli skarbowej i Służby Celnej. Jak podkreślano w uzasadnieniu projektu, utworzono administrację skonsolidowaną, a konsolidacja dotyczyła dwóch obszarów:

— konsolidacji przedmiotowej departamentów na poziomie centralnym w Ministerstwie Finansów,

- konsolidacji podmiotowej na poziomie regionalnym oraz lokalnym izb i urzędów skarbowych, urzędów kontroli skarbowych, izb i urzędów celnych w izby administracji skarbowej oraz w urzędy skarbowe i urzędy celno-skarbowe.

W takiej skonsolidowanej administracji skarbowej funkcjonują następujące organy KAS: minister właściwy do spraw finansów publicznych; Szef KAS; dyrektor Krajowej Informacji Skarbowej; dyrektor izby administracji skarbowej; naczelnik urzędu skarbowego; naczelnik urzędu celno-skarbowego.

Minister właściwy do spraw finansów publicznych jest odpowiedzialny za koordynowanie i współdziałanie w kształtowaniu polityki państwa w zakresie zadań KAS. Rola główna, z punktu widzenia realizacji zadań KAS, przypisana została Szefowi KAS. Zmieniła się pozycja prawna naczelnika urzędu skarbowego. Przejął on, według nowych rozwiązań, kompetencje dotychczasowego naczelnika urzędu skarbowego i naczelnika urzędu celnego w zakresie między innymi poboru podatków, należności celnych, opłat oraz niepodatkowych należności budżetowych, jak też innych należności na podstawie odrębnych przepisów czy też egzekucji administracyjnej należności pieniężnych. $Z$ kolei nowo utworzony organ - naczelnik urzędu celno-skarbowego - realizuje zadania związane między innymi z wykonywaniem kontroli celno-skarbowej, ustalaniem i określaniem podatków, opłat i niepodatkowych należności budżetowych oraz innych należności na podstawie odrębnych przepisów czy też obejmowaniem towarów procedurami celnymi oraz wykonywaniem innych czynności przewidzianych przepisami prawa celnego.

Nadzór nad realizacją zadań wykonywanych przez naczelników urzędów skarbowych i naczelników urzędów celno-skarbowych powierzony został dyrektorowi izby administracji skarbowej.

5 Uzasadnienie do poselskiego projektu ustawy o Krajowej Administracji Skarbowej (druk 826); uzasadnienie liczy 121 stron. 
Terenowe organy administracji celno-skarbowej pozostały, jak dotychczas, w strukturze administracji rządowej niezespolonej w województwie.

W skład KAS wchodzą następujące jednostki organizacyjne (art. 36 ust. 1): licznych;

— komórki organizacyjne urzędu obsługującego ministra ds. finansów pub-

- Krajowa Informacja Skarbowa - jako jednostka organizacyjna pomocna dyrektorowi Krajowej Informacji Skarbowej w wykonywaniu jego zadań,

— izby administracji skarbowej — jako jednostki organizacyjne pomocne dyrektorom izb administracji skarbowej w wykonywaniu ich zadań,

— urzędy skarbowe - jako jednostki organizacyjne pomocne naczelnikom urzędów skarbowych w wykonywaniu ich zadań,

- urzędy celno-skarbowe wraz z podległymi oddziałami celnymi — jako jednostki organizacyjne pomocne naczelnikom urzędów celno-skarbowych w wykonywaniu ich zadań,

— Krajowa Szkoła Skarbowości — jako jednostka organizacyjna służąca realizowaniu zadań w zakresie kształcenia i doskonalenia zawodowego kadr KAS,

- Centrum Informatyki KAS — jako jednostka organizacyjna służąca Centrum Informatyki KAS w wykonywaniu zadań.

\section{PRAWNE UWARUNKOWANIA DOKONYWANYCH ZMIAN W ZATRUDNIANIU PRACOWNIKÓW I FUNKCJONARIUSZY W NOWYCH STRUKTURACH ADMINISTRACJI CELNO-SKARBOWEJ}

Reforma administracji celnej i skarbowej, zniesienie dotychczasowych organów centralnych i terenowych tej administracji, spowodowała nie tylko powoływanie nowych organów i zmianę ich właściwości rzeczowej, lecz przede wszystkim określone skutki dla pracowników i funkcjonariuszy zatrudnionych w dotychczasowych strukturach administracji skarbowej i celnej. Inaczej mówiąc — skutki personalne prowadzące nie tylko do zmiany warunków zatrudnienia czy służby, lecz także do wygaśnięcia z mocy prawa wcześniejszych stosunków pracy lub służby ${ }^{6}$.

Zgodnie $\mathrm{z}$ unormowaniami zawartymi w ustawie wprowadzającej izba skarbowa, po wejściu w życie nowych przepisów, kontynuowała działalność i stała się izbą administracji skarbowej. Izba ta połączona została z mającymi siedzibę w tym samym województwie izbą celną i urzędem kontroli skarbowej (art. 160 ust. 2 i 4). Zniesione zostały urzędy celne (ust. 8), a utworzone urzędy celno-skarbowe (art. 163). Pozostały urzędy skarbowe, a naczelnicy tych urzędów stali się organami KAS. Ta zmiana organizacyjna nie nastąpiła jednak tylko w wyniku połączenia

${ }^{6}$ E. Ura, S. Pieprzny, op. cit., s. 186. 
dotychczasowych jednostek, przejęcia praw i zobowiązań dawnych jednostek organizacyjnych przez nowe, ale pociągnęła za sobą istotne zmiany w dotychczasowych stosunkach zatrudnienia pracowników, a jeszcze większe w odniesieniu do funkcjonariuszy Służby Celnej. Podstawą tych zmian stał się art. 170 ustawy wprowadzającej:

1. Stosunki pracy osób zatrudnionych w jednostkach KAS, o których mowa w art. 36 ust. 1 pkt 2, 3 i 6 ustawy, o której mowa w art. 1, oraz stosunki służbowe osób pełniących służbę w jednostkach KAS, o których mowa w art. 36 ust. 1 pkt 2, 3 i 6 ustawy, o której mowa w art. 1, wygasają:

1. z dniem 31 sierpnia 2017 r., jeżeli osoby te w terminie do dnia 31 maja 2017 r., nie otrzymają pisemnej propozycji określającej nowe warunki zatrudnienia albo pełnienia służby;

2. po upływie 3 miesięcy, licząc od miesiąca następującego po miesiącu, w którym pracownik albo funkcjonariusz złożył oświadczenie o odmowie przyjęcia propozycji zatrudnienia albo pełnienia służby, jednak nie później niż dnia 31 sierpnia $2017 \mathrm{r}$.

3. Pracownik albo funkcjonariusz, któremu przedstawiono propozycję zatrudnienia albo pełnienia służby, składa w terminie 14 dni od dnia jej otrzymania oświadczenie o przyjęciu albo odmowie przyjęcia propozycji. Niezłożenie oświadczenia w tym terminie jest równoznaczne z odmową przyjęcia propozycji zatrudnienia albo pełnienia służby.

4. W przypadku, o którym mowa w ust. 1, wygaśnięcie stosunku służbowego funkcjonariusza traktuje się jak zwolnienie ze służby.

5. W przypadku, o którym mowa w ust. 1, pracownikom oraz funkcjonariuszom przysługują świadczenia należne odpowiednio w związku z likwidacją urzędu albo zniesieniem jednostki organizacyjnej w rozumieniu ustawy uchylanej w art. 159 pkt 3.

6. Przepisów ust. 1 i 4 nie stosuje się do urzędników służby cywilnej, do których mają zastosowanie przepisy rozdziału 5 ustawy z dnia 21 listopada 2008 r. o służbie cywilnej (Dz.U. z 2016 r. poz. 1345, 1605 i 1807).

7. Przepisy ust. 1-5 stosuje się odpowiednio do pracowników, o których mowa w art. 167 ust. 1.

8. Pracownicy, o których mowa w art. 167, oraz funkcjonariusze pełniący służbę w urzędzie obsługującym ministra właściwego do spraw finansów publicznych, którym nie zostanie złożona propozycja określająca nowe warunki zatrudnienia albo pełnienia służby w terminie do dnia 31 maja 2017 r., otrzymują pisemną informację o braku propozycji .

Rozbudowana treść tego artykułu, która dla przeciętnego obywatela zapewne nie do końca jest zrozumiała, przyniosła ewidentne skutki w statusie prawnym funkcjonariuszy Służby Celnej. Artykuł ten należy analizować z art. 165 ust. 3 ustawy, z którego wynika, że pracownicy zatrudnieni w izbach celnych oraz urzędach kontroli skarbowej oraz funkcjonariusze celni pełniący służbę w izbach

7 Art. 36 ust. 1 pkt 1 ustawy o KAS dotyczy komórek organizacyjnych urzędu obsługującego ministra do spraw finansów publicznych, pkt 2 - Krajowej Informacji Skarbowej, pkt 3 - izb administracji skarbowej, pkt 6 - Krajowej Szkoły Skarbowości; art. 159 pkt 3 ustawy wprowadzającej uchyla ustawę o Służbie Celnej; art. 167 ust. 1 ustawy wprowadzającej dotyczy pracowników zatrudnionych w urzędzie obsługującym ministra właściwego do spraw finansów publicznych i wykonujących zadania w komórkach organizacyjnych urzędu obsługującego ministra właściwego do spraw finansów publicznych oraz ministra właściwego do spraw instytucji finansowych, którzy stają się pracownikami zatrudnionymi w urzędzie obsługującym ministra właściwego do spraw finansów publicznych, wykonują zadania KAS i zachowują ciągłość pracy — z zastrzeżeniem art. 170. 
celnych albo w komórkach urzędu obsługującego ministra właściwego do spraw finansów publicznych stali się z dniem wejścia w życie ustawy o KAS, odpowiednio, pracownikami zatrudnionymi w jednostkach organizacyjnych KAS albo funkcjonariuszami Służby Celno-Skarbowej i zachowują ciągłość pracy i służby (ust. 2), ale jak zaznaczył ustawodawca — ,z zastrzeżeniem art. 170”. To niewinne, wydawać by się mogło, zastrzeżenie oznaczało natomiast, że z dniem wejścia w życie ustawy o KAS dotychczasowi pracownicy i funkcjonariusze wymienionych jednostek organizacyjnych, którzy stali się z mocy prawa pracownikami i funkcjonariuszami nowej administracji celno-skarbowej, zostali jednocześnie odgórnie podzieleni na trzy grupy:

1. w pierwszej grupie znaleźli się ci, którym kierownicy nowo utworzonych jednostek organizacyjnych KAS wymienionych w art. 170, 165 i 167 ustawy wprowadzającej przedstawili do dnia 31 maja 2017 roku pisemną propozycję określającą nowe warunki zatrudnienia albo pełnienia służby i warunki te przyjęli;

2. w drugiej ci, którzy co prawda otrzymali propozycję nowych warunków zatrudnienia lub pełnienia służby, ale złożyli oświadczenie o jej odmowie; w takim przypadku ich zatrudnienie lub stosunki służbowe wygasały po upływie trzech miesięcy, licząc od miesiąca następującego po miesiącu, w którym takie oświadczenie złożyli. Termin na złożenie oświadczenia wynosił czternaście dni od otrzymania propozycji, a niezłożenie w tym terminie oświadczenia było jednoznaczne z odmową przyjęcia propozycji zatrudnienia lub pełnienia służby;

3. do trzeciej grupy należy zakwalifikować tych pracowników i funkcjonariuszy, którzy nie otrzymali żadnej propozycji dalszego zatrudnienia lub służby, co oznaczało, że „nowa władza” nie widziała możliwości dalszej ich pracy czy służby w strukturach KAS. Ich stosunki zatrudnienia z mocy prawa wygasły z dniem 31 sierpnia 2017 roku. Jest to więc unormowanie szczególne, będące odstępstwem od ogólnych przepisów wymagających oświadczenia woli (decyzji przy stosunku służbowym) co do rozwiązania stosunków pracy lub służby w ustawowo określonych przypadkach.

Dodatkowo, w odniesieniu do funkcjonariuszy, wyodrębnić jeszcze trzeba grupę tych, którzy otrzymali propozycję dalszego zatrudnienia ale nie na podstawie stosunku służbowego jako funkcjonariusz Służby Celno-Skarbowej, a na podstawie umowy o pracę w służbie cywilnej, czyli propozycję „ucywilnienia”, co oznaczało jednocześnie wygaśnięcie ich dotychczasowego stosunku służbowego. Ustawodawca podkreślił, że wygaśnięcie stosunku służbowego w odniesieniu do funkcjonariuszy celnych traktowane jest jak zwolnienie ze służby.

Należy też wskazać na treść art. 165 ust. 7 ustawy wprowadzającej, stanowiący, że

dyrektor Krajowej Informacji Skarbowej, dyrektor izby administracji skarbowej oraz dyrektor Krajowej Szkoły Skarbowości składają odpowiednio pracownikom oraz funkcjonariuszom, w terminie do dnia 31 maja 2017 r., pisemną propozycję określającą nowe warunki zatrudnienia albo pełnienia służby, która uwzględnia posiadane kwalifikacje i przebieg dotychczasowej pracy lub służby, a także dotychczasowe miejsce zamieszkania. 
Przepisem art. 159 pkt 3 ustawy wprowadzającej uchylona została ustawa z 27 sierpnia 2009 roku o Służbie Celnej ${ }^{8}$.

\section{INTERPRETACJA ART. 165 UST. 7 USTAWY WPROWADZAJĄCEJ W STOSUNKU DO FUNKCJONARIUSZY W PROCESIE JEGO STOSOWANIA $^{9}$}

Korzystając z tych rozwiązań ustawowych, dyrektorzy izb administracji skarbowej przedstawili w maju 2017 roku niektórym funkcjonariuszom propozycję dalszego zatrudnienia, ale na podstawie umowy o pracę na czas nieokreślony w służbie cywilnej. Zaproponowane warunki, po ich przyjęciu, obowiązywać zaczęły od 1 czerwca 2017 roku. To oznaczało wygaśnięcie dotychczasowych stosunków służbowych i kontynuowanie zatrudnienia na podstawie umowy o pracę na czas nieokreślony.

Przypomnieć tu wypada, że zgodnie z wcześniej obowiązującą ustawą o Służbie Celnej stosunek służbowy funkcjonariusza powstawał w wyniku mianowania, na podstawie zgłoszenia się do służby (art. 78 ust. 1). Mianowania do służby przygotowawczej albo stałej dokonywał Szef Służby Celnej albo upoważniony przez niego kierownik urzędu. Kierownik urzędu, w którym funkcjonariusz pełnił służbę, w terminie nie dłuższym niż siedem dni od dnia mianowania, mianował funkcjonariusza na stopień służbowy oraz określał, w formie pisemnej, stanowisko służbowe, uposażenie oraz miejsce pełnienia służby (art. 82 ust. 1 i 5). Artykuł 96 ustawy przewidywał, że w przypadku zniesienia jednostki organizacyjnej kierownik urzędu wstępujący w prawa i obowiązki kierownika znoszonej jednostki proponował, w terminie trzydziestu dni od dnia zniesienia jednostki organizacyjnej, funkcjonariuszowi warunki pełnienia służby, uwzględniające jego kwalifikacje i doświadczenie, oraz wskazywał termin — nie krótszy niż czternaście dni - do którego funkcjonariusz mógł złożyć oświadczenie o przyjęciu bądź odmowie przyjęcia proponowanych warunków. W przypadku odmowy przyjęcia proponowanych warunków lub niezłożenia oświadczenia we wskazanym terminie funkcjonariusza w służbie stałej zwalniano ze służby po upływie trzech miesięcy (dwu tygodni — w przypadku funkcjonariuszy w służbie przygotowawczej). Ustawodawca przewidział ponadto możliwość złożenia funkcjonariuszowi propozycji przeniesienia do służby cywilnej w urzędzie obsługującym ministra właściwego

8 Tekst jedn. Dz.U. z 2016 r. poz. 1799 ze zm.

9 Niniejszy stan przedstawiono na podstawie treści odwołania w sprawie IV P 431/17 złożonego do Sądu Rejonowego w Rzeszowie oraz skargi na bezczynność organu złożonej do WSA w Rzeszowie, II SA/Rz 963/17. Spraw w tożsamym stanie faktycznym i prawnym w skali kraju jest dużo. Funkcjonariusze składają skargi do sądów administracyjnych oraz tożsamej treści do sądów pracy. Stanowisko niektórych sądów administracyjnych wyrażone w wydanych wyrokach zostanie przedstawione $\mathrm{w}$ dalszej części. 
do spraw finansów publicznych albo jednostkach organizacyjnych podległych lub nadzorowanych przez tego ministra. Propozycję przedstawiał dyrektor generalny lub kierownik urzędu wykonujący jego zadania. Funkcjonariusz składał pisemne oświadczenie o przyjęciu lub odmowie przyjęcia propozycji. Dotychczasowy stosunek służbowy funkcjonariusza, który przyjął propozycję, przekształcał się w stosunek pracy na podstawie umowy o pracę, natomiast stosunek służbowy funkcjonariusza, który odmówił przyjęcia złożonej propozycji, się nie zmieniał. $\mathrm{Z}$ wnioskiem o przeniesienie mógł wystąpić również funkcjonariusz (art. 98).

Wracając do przyjętych rozwiązań w art. 165 ust. 7 ustawy wprowadzającej, powstała na tle jego literalnej interpretacji wątpliwość, która w konsekwencji jest przedmiotem treści odwołań i skarg składanych przez ,ucywilnionych” funkcjonariuszy celnych. W uzasadnieniu odwołań podnoszonych jest kilka aspektów. Wskazuje się, że użyty przez ustawodawcę zwrot „odpowiednio” oznacza wyraźnie, że dotychczasowi pracownicy otrzymają propozycję pracy, a funkcjonariusze celni - propozycję służby. Ponadto odwołujący się celnicy wskazują na dalszą treść tego przepisu, a mianowicie że ustawodawca precyzyjnie i jednoznacznie wymienił trzy przesłanki, jakimi powinien kierować się dyrektor izby administracji skarbowej, składając propozycję pełnienia służby, to jest: kwalifikacje, przebieg dotychczasowej służby, dotychczasowe miejsce zamieszkania. W tej sytuacji kwestionują zwolnienie funkcjonariusza ze służby na skutek ,ucywilnienia", zarzucając dodatkowo niepodanie kryteriów, którymi kierował się dyrektor, nie przedstawiając funkcjonariuszowi propozycji służby. Odwołujący zauważają też, że ustawodawca posługuje się dysjunkcją ,albo”, co powinno być interpretowane wyłącznie $\mathrm{w}$ ten sposób, że pracownicy zatrudnieni w izbach celnych oraz urzędach kontroli skarbowej mogli stać się wyłącznie pracownikami zatrudnionymi w jednostkach organizacyjnych KAS, a funkcjonariusze celni pełniący służbę w izbach celnych albo w komórkach urzędu obsługującego ministra właściwego do spraw finansów publicznych mogli się stać wyłącznie funkcjonariuszami Służby Celno-Skarbowej pełniącymi służbę w jednostkach KAS. Według odwołujących się inna interpretacja stosowana w praktyce przez „ucywilnienie” części funkcjonariuszy jest niezgodna z konstytucją, gdyż narusza zasadę równości i prowadzi do dyskryminacji tych funkcjonariuszy, którym nie zaproponowano służby, tylko zatrudnienie, tym bardziej że zgodnie z obowiązującymi wcześniej unormowaniami Służba Celna była jednolitą umundurowaną formacją. Według odwołujących się „ucywilnienie” części funkcjonariuszy narusza dodatkowo zasadę sprawiedliwości społecznej i zasadę państwa prawnego wyrażoną w art. 2 Konstytucji RP. W końcu w odwołaniach podnoszone jest i to, że funkcjonariusze, którzy przez złożoną propozycję zatrudnienia na podstawie umowy o pracę stali się pracownikami, nie otrzymali decyzji administracyjnej zwalniającej ich ze służby, co uniemożliwia im złożenie odwołania do Szefa KAS, stąd odwołania wnoszą bezpośrednio do sądu administracyjnego. 
Argumentem podnoszonym w odwołaniach jest i to, że obowiązujące obecnie przepisy naruszają prawa nabyte funkcjonariuszy. Przedstawienie propozycji „ucywilnienia” pod groźbą utraty zatrudnienia, gdy do funkcjonariusza nie ma żadnych zastrzeżeń, jest bowiem sprzeczne z zasadą praworządności, zaufania do organów państwa i z zasadą ochrony stosunku służbowego funkcjonariuszy służby publicznej. Jako uzasadnienie takiej argumentacji podano obowiązujący w uchylonej ustawie o Służbie Celnej art. 98, który gwarantował, że nieprzyjęcie propozycji zatrudnienia w służbie cywilnej nie skutkowało zwolnieniem ze służby ${ }^{10}$.

Autorzy odwołań uzasadniają swoją argumentację również treścią art. 171 ustawy wprowadzającej, zgodnie z którym:

W przypadku przyjęcia propozycji zatrudnienia albo pełnienia służby, z dniem określonym w propozycji, dotychczasowy:

1. stosunek pracy na podstawie umowy o pracę na czas nieokreślony albo określony,

2. stosunek służby w służbie przygotowawczej albo stałej

— przekształca się odpowiednio w stosunek pracy albo służby w Służbie Celno-Skarbowej, odpowiednio na podstawie umowy o pracę na czas nieokreślony albo określony, mianowania do służby przygotowawczej albo służby stałej.

Ponadto podkreślali, że ustawodawca wskazał w art. 169 ust. 4, że propozycja służby jest decyzją, od której przysługuje wniosek o ponowne rozpatrzenie sprawy $^{11}$. To, w ocenie skarżących, oznacza, że decyzja taka jest decyzją z zakresu zmiany dotychczasowego stosunku służbowego i na jej podstawie nie może powstać stosunek służbowy funkcjonariusza w wyniku przekształcenia ze stosunku pracy.

W konkluzji skarżący uznają, że ustawodawca ustanowił możliwość przedstawienia propozycji służby wyłącznie dotychczasowym funkcjonariuszom, a propozycji zatrudnienia wyłącznie dotychczasowym pracownikom. Na taki zamiar ustawodawcy wskazuje użycie zwrotu ,odpowiednio”. W tej sytuacji, wobec braku stosownych decyzji administracyjnych o zwolnieniu ze służby, dotychczasowy stosunek służbowy na podstawie aktu mianowania powinien trwać nadal mimo przedstawienia propozycji pracy.

10 Odwołujący powołują się w treści odwołań na wiele wyroków zarówno sądów administracyjnych, jak i Trybunału Konstytucyjnego, na przykład wyroki TK z dnia: 14 grudnia 1999 r., SK 14/98, OTK ZU 1999, nr 7, poz. 163; 19 października 2004 r., K 1/04, OTK-A 2004, nr 9/93; 13 lutego 2007 r., K 46/05, OTK-A 2007, nr 2, poz. 10; 23 września 1997 r., K 25/96, OTK ZU 1997, nr 3-4, poz. 36; 27 stycznia 2003 r., SK 27/02, OTK ZU 2003, nr 1/A, poz. 2; wyrok NSA z dnia 7 marca 2017 r., I OSK 316/2016, CBOSA; wyrok WSA w Bydgoszczy z dnia 28 października 2015 r., II SA/Bd 878/15; wyrok WSA w Warszawie z dnia 24 października 2013 r., II SA/Wa 1188/13.

11 Przytaczane jest tu też orzecznictwo: wyrok NSA z dnia 3 listopada 2010, II SK 949/10; i uchwała SN z dnia 8 czerwca 2010 r., II PZP 5/10. 


\section{DOTYCHCZASOWE STANOWISKA SĄDÓW ADMINISTRACYJNYCH}

W orzecznictwie wojewódzkich sądów administracyjnych wystąpiła rozbieżność co do możliwości poddania kontroli sądowoadministracyjnej działań organów KAS podjętych na podstawie art. 165 ust. 7 ustawy wprowadzającej. Wydawane są przez niektóre sądy postanowienia o braku kognicji sądów administracyjnych w tego typu sprawach ${ }^{12}$. Innego zdania był WSA w Szczecinie. Sąd ten, rozpatrując sprawę w tożsamym jak przedstawiony tu stanie faktycznym i prawnym, wydał wyrok w dniu 4 października 2017 roku (II SA 897/17, LEX nr 2377612), w którym uznał, że pisemna propozycja złożona funkcjonariuszowi, określająca nowe warunki zatrudnienia $\mathrm{w}$ izbie administracji skarbowej, jest decyzją w rozumieniu art. $104 \S 1$ k.p.a., która podlega zaskarżeniu. Argumentacja wyroku sprowadza się do stwierdzeń, że:

1. norma art. 169 ust. 4 ustawy wprowadzającej narusza konstytucyjną zasadę równości, słusznych oczekiwań, wreszcie prawo do sądu, przez zaniechanie ustawodawcy wprowadzenia mechanizmu ochrony prawnej dla tych osób, które nie otrzymają propozycji pełnienia służby, otrzymają zaś propozycję zatrudnienia w KAS na podstawie umowy o pracę;

2. skoro ustawodawca objął ochroną tych funkcjonariuszy, którym w miejsce służby celnej zaproponowano służbę w Służbie Celno-Skarbowej, to za rażąco niesprawiedliwe należy uznać nieobjęcie taką ochroną tych funkcjonariuszy, którym dotychczasowy stosunek mianowania i służby zastępuje się formą dla nich mniej korzystną — stosunkiem pracy. W ocenie Sądu funkcjonariusz, który status ten traci, ma prawo do rzetelnego uzasadnienia, zawartego w decyzji administracyjnej, w jaki sposób jego kwalifikacje i przebieg dotychczasowej służby uzasadniają taką, a nie inną zmianę, tym bardziej że decyzja w zakresie nowych warunków zatrudnienia $\mathrm{w}$ istocie ma znacznie szersze pole oddziaływania, wobec czego funkcjonariusz powinien nie tylko mieć prawo do poznania argumentów, jakie doprowadziły organ do przekonania, że tym funkcjonariuszem nie powinien już być. Rozstrzygnięcie o przeniesieniu funkcjonariusza celnego do pracy na podstawie umowy o pracę nie tylko pozbawia takiego funkcjonariusza dotychczasowej ochrony, lecz także, potencjalnie, eliminuje go z katalogu osób objętych uprawnieniami emerytalnymi, które przysługują funkcjonariuszom; może spowodować obniżenie wynagrodzenia (brakuje gwarancji dotychczasowego uposażenia); pozbawia funkcjonariusza dotychczasowych dodatków z tytułu posiadanego stopnia służbowego czy uprawnienia do dodatkowego urlopu wypoczynkowego; przerywa jego ścieżkę kariery zawodowej w Służbie Celnej i powoduje konieczność niezwłocznego przystosowania się do nowych warunków, nawet gdy spędził w for-

12 Postanowienia: WSA w Szczecinie z dnia 29 sierpnia 2017 r., II SA/Sz 904/17; WSA w Poznaniu z dnia 13 września 2017 r., II SA/Po 765/17; WSA w Gdańsku z dnia 16 października 2017 r., III SA/Gd 819/17, zob. orzeczenia.nsa.gov.pl. 
macji kilkanaście lat; deprecjonuje akt mianowania, nie mówiąc już o poczuciu frustracji i niesprawiedliwości itp.;

3. pozbawienie funkcjonariusza, który otrzymuje propozycję zatrudnienia w KAS na podstawie umowy o pracę, ochrony w postaci możliwości złożenia wniosku o ponowne rozpatrzenie sprawy oznacza de facto poddanie funkcjonariuszy celnych procesowi ,ucywilnienia” bez zapewnienia im środków odwoławczych;

4. wprowadzone w art. 169 ust. 4 ustawy regulacje pomijające ochronę prawną funkcjonariuszy przenoszonych ze służby do pracy (w konsekwencji ochronę prawną ich stosunku służbowego) powinny pozostawać w racjonalnym związku z przyczynami, które rodzą skutek prawny w postaci zmiany stosunku służby na stosunek zatrudnienia (i w tym zakresie legalność tych decyzji podlega kontroli sądowej). To jednak nie usprawiedliwia różnicowania ochrony ich stosunku służbowego w sposób niekorzystny dla tych funkcjonariuszy, którym pełnienia dalszej służby nie zaproponowano;

5. przyjęta przez ustawodawcę norma $\mathrm{z}$ art. 169 ust. $4 \mathrm{w}$ zakresie, w jakim pomija pisemną propozycję zatrudnienia, narusza zasadę równości. Brakuje ratio legis wprowadzonego rozwiązania odmiennego potraktowania funkcjonariuszy, którym złożono pisemną propozycję pełnienia służby i funkcjonariuszy, którym złożono pisemną propozycję zatrudnienia, co implikuje wniosek o naruszeniu tej zasady;

6. wobec stwierdzenia niekonstytucyjności normy zawartej w art. 169 ust. 4 ustawy w zakresie, w jakim pomija pisemną propozycję określającą nowe warunki zatrudnienia, pisemna propozycja nowych warunków zatrudnienia złożona funkcjonariuszowi jest decyzją administracyjną.

Inne stanowisko i argumentację zaprezentował WSA w Olsztynie w wyroku z 19 października 2017 roku (II SA/Ol 672/17, CBOSA). Sąd ten uznał, że złożenie funkcjonariuszowi pisemnej propozycji określającej warunki zatrudnienia w ramach korpusu służby cywilnej w Izbie Administracji Skarbowej poprzedziła czynność organu z zakresu administracji publicznej dotycząca uprawnień funkcjonariusza wynikających z przepisów prawa, która na mocy art. $3 \S 2$ pkt 4 ustawy z dnia 30 sierpnia 2002 roku. Prawo o postępowaniu przed sądami administracyjnymi podlega kontroli sądów administracyjnych. Sąd stwierdził, że złożenie funkcjonariuszowi przez organ pisemnej propozycji określającej warunki zatrudnienia (a więc wydanie aktu) było jedynie skutkiem podjętej uprzednio przez organ czynności, która w sposób władczy i jednostronny kształtowała jego sytuację prawną. Ustawodawca wyposażył bowiem właściwe organy w kompetencje do władczego rozstrzygnięcia zarówno o tym, których funkcjonariuszy pozostawić w nowej strukturze KAS, jak i o tym, czy złożyć im propozycję określającą warunki zatrudnienia, czy warunki pełnienia służby. Mimo wyposażenia właściwych organów w kompetencje do władczego rozstrzygania o sytuacji prawnej funkcjonariuszy ustawodawca nie wskazał formy prawnej działania organu w tym 
obszarze, analiza zaś przepisów ustawy wprowadzającej nie pozwala na przyjęcie domniemania formy decyzji administracyjnej.

Sąd w dalszych wywodach stwierdził, że powziął wątpliwość co do legalności prawa, na podstawie którego organ podjął zaskarżoną czynność. Podkreślił, że wykładnia gramatyczna art. 165 ust. 7 ustawy wprowadzającej, powołanego przez organ jako podstawa prawna złożenia funkcjonariuszowi pisemnej propozycji określającej warunki zatrudnienia w KAS, nie jest wystarczająca do prawidłowego odkodowania znaczenia norm prawnych zawartych w tym przepisie. Złożenie tej propozycji było jedynie skutkiem podjętej uprzednio przez organ czynności, która w sposób władczy i jednostronny kształtowała sytuację prawną skarżącego. W art. 165 ust. 7 ustawy określone zostały kryteria: ,posiadane kwalifikacje i przebieg dotychczasowej pracy lub służby, a także dotychczasowe miejsce zamieszkania". Przez pryzmat tych kryteriów możliwe jest dokonanie obiektywnej oceny przydatności konkretnej osoby (zarówno pracownika, jak i funkcjonariusza) do realizacji zadań w KAS. W przepisie tym nie zawarto natomiast żadnych konkretnych kryteriów, którymi organ powinien się kierować w stadium drugim omawianej czynności, w którym organ rozstrzygnął o nawiązaniu z funkcjonariuszem stosunku pracy, a nie stosunku służby. W tym zakresie wystąpiło pominięcie ustawodawcze, co implikowało konieczność rozważenia przez sąd administracyjny, czy nie zachodzi potrzeba bezpośredniego zastosowania konstytucji w celu wypełnienia takiej luki treścią normatywną. Dlatego sąd za konieczne uznał wypełnienie luki prawnej w art. 165 ust. 7 ustawy w drodze bezpośredniego zastosowania przepisów Konstytucji RP, gdyż tylko w taki sposób możliwe było wydanie wyroku chroniącego wartości konstytucyjne i prawidłowo realizującego prawo jednostki do sprawiedliwego wyroku. Podstawowym przepisem konstytucyjnym znajdującym zastosowanie w sprawie jest, według sądu, art. 60 Konstytucji RP: „obywatele polscy korzystający z pełni praw publicznych mają prawo dostępu do służby publicznej na jednakowych zasadach". Sąd przywołał tu orzecznictwo TK, w którym przyjęto, że przepis ten obejmuje nie tylko etap naboru do służby publicznej, lecz także zasady wykonywania tej służby i zasady zwalniania ze służby publicznej ${ }^{13}$. Dalej sąd wywodzi, że

Nie powinno budzić wątpliwości, że art. 60 Konstytucji RP znajduje zastosowanie również w przypadku przekształcenia stosunku prawnego łączącego daną osobę z państwem, czy organem państwa - w szczególności przekształcenia stosunku służbowego, którego podstawą jest decyzja administracyjna, w stosunek pracy, którego podstawą jest umowa o pracę. Skoro w kontrolowanej sprawie organ nie wykazał żadnych obiektywnych przesłanek uzasadniających złożenie skarżącemu propozycji zatrudnienia a nie propozycji służby, należało opowiedzieć się za trwałością stosunku służby skarżącego i obok stwierdzenia bezskuteczności zaskarżonej czynności, na podstawie art. $146 \S 2$ p.p.s.a., uznać uprawnienie skarżącego do złożenia mu propozycji służby.

13 Na przykład wyrok TK z dnia 23 stycznia 2014 r., K 51/12, OTK 2014, nr 1, poz. 4. 


\section{KONKLUZJA}

Nie pierwszy to raz, kiedy ustawodawca sięga do rozwiązań, na mocy których następuje wygaśnięcie stosunku pracy z mocy prawa, gdy nie zostaną pracownikowi zaproponowane nowe warunki pracy na dalszy okres albo gdy pracownik nie przyjął nowych warunków pracy. Tak było w ustawie o pracownikach samorządowych z 1990 roku — w związku z utworzeniem samorządu terytorialnego na stopniu gminy, tak było przy wprowadzaniu kolejnego etapu reformy ustrojowej w latach 1998-1999 i utworzeniu samorządu powiatowego i samorządu województwa. Trybunał Konstytucyjny uznał wówczas, że są to rozwiązania nadzwyczajne i możliwe do zastosowania tylko w wyjątkowych sytuacjach, związanych z koniecznością realizowania innych ważnych wartości konstytucyjnych $^{14}$. Czy w związku z tym rozwiązania przyjęte w stosunku do pracowników i funkcjonariuszy administracji celno-skarbowej uznać można za uzasadnione wyjątkowymi sytuacjami, na które zwracał uwagę Trybunał? Czy doprowadzenie do wygaśnięcia stosunków służbowych funkcjonariuszy nie tylko w wyniku niezaproponowania im nowych warunków służby, lecz także wskutek ,ucywilnienia" dotychczasowych stosunków służbowych przez zaproponowanie dalszego zatrudnienia na podstawie umowy o pracę nie stanowi nadużycia prawa przez dyrektorów izb administracji celnej? Pytania można oczywiście mnożyć. Zauważyć zresztą trzeba, że podobne rozwiązania, to jest wygaśnięcie stosunków zatrudnienia z mocy ustawy, wprowadzono również w ustawie z 10 lutego 2017 roku — przepisy wprowadzające ustawę o Krajowym Ośrodku Wsparcia Rolnictwa ${ }^{15}$ w związku z reformą agencji działających na rzecz rolnictwa ${ }^{16}$. Czy więc reforma agencji rolnych, administracji celno-skarbowej czy innych struktur administracji jest wystarczającym uzasadnieniem wprowadzanych przez ustawodawcę rozwiązań, które dotyczą pracowników i funkcjonariuszy zatrudnionych w poprzednich strukturach organizacyjnych? Czy są to rzeczywiście wyjątkowe sytuacje, związane z koniecznością realizowania innych ważnych wartości konstytucyjnych, o których mówił Trybunał Konstytucyjny?

Trzeba przy tym wskazać jeszcze na jeden aspekt wiążący się z takimi rozwiązaniami. Pozostawienie nowo powoływanym dyrektorom izb administracji skarbowej tak dużej władzy dyskrecjonalnej w zakresie oceny, których z dotychczasowych funkcjonariuszy pozostawić w służbie, którym zaproponować ich „ucywilnienie", a którym w ogóle nic nie proponować, bo i tak z mocy ustawy ich stosunki służbowe wygasną, doprowadzić może do osłabienia sprawności działania administracji celno-skarbowej.

14 Wyrok TK z dnia 13 marca 2000 r., K 1/99, OTK 2000, nr 2, poz. 59.

15 Dz.U. z 2017 r. poz. 624.

16 Ustawa z 10 lutego 2017 r. o Krajowym Ośrodku Wsparcia Rolnictwa (tekst jedn. Dz.U. z 2018 r. poz. 1154). 
Spory powstałe na tym tle, jak wskazano, są obecnie przedmiotem ocen sądów administracyjnych. Już sam fakt, że w tożsamym stanie faktycznym i prawnym zapadają różne wyroki, świadczy o niedoskonałości legislacyjnej. Na wypracowanie $\mathrm{w}$ miarę jednolitego stanowiska $\mathrm{w}$ orzecznictwie trzeba będzie poczekać. Być może zostanie ono wypracowane przez NSA. Ale już teraz zauważyć należy, że niezależnie od treści wyroków w uzasadnieniach wydawanych wyroków sądy odwoływały się do zasad konstytucyjnych.

\title{
CHANGE OF THE LEGAL STATUS OF THE CUSTOMS SERVICE OFFICER FROM THE ADMINISTRATIVE AND LEGAL RELATION TO THE CONTRACTUAL RELATION - IN THE CONTEXT OF THE RULE OF LAW
}

\author{
Summary
}

On March 1, 2017, acts reforming the customs and tax administration system came into force. They introduced not only changes in the system of organs and organizational structure of this administration, but also significantly influenced the legal status of Customs Service officers. Not all officers were offered further service in the newly created customs and tax administration. Some of them received offers of employment in positions of civil part - in general has not been employed for a further period. In both cases, the relationship was terminated, which in the light of the adopted statutory solutions is treated as an exemption from service. A very large group of officers filed appeals to administrative courts, some of them - also to common courts. Against the background of the provisions formulated in such a way, the question arises: whether the change of the legal status of the Customs Service officer from the administrative and legal relation to the contractual relation made by the director of the customs chamber as part of the powers entrusted to him, is in line with the rule of law. The answer to this question will ultimately be given by the courts. The study will, however, present general observations regarding the existing situation.

Keywords: reform of customs and tax administration, officer of the Customs Service, right to court, dismissal from service

\section{BIBLIOGRAFIA}

Ura E., Pieprzny S., Reforma administracji celno-skarbowej przyczyna wygaśnięcia stosunków zatrudnienia z mocy prawa pracowników i funkcjonariuszy tej administracji, [w:] Przemiany cywilizacyjne a funkcjonowanie administracji publicznej. Księga jubileuszowa dedykowana Profesorowi Bronisławowi Jastrzębskiemu w dziewięćdziesiąta rocznicę urodzin, red. J. Strzelecki, M. Giżyńska, Płock 2017. 